\title{
Respon Perkecambahan Tembakau (Nicotiana tabacum) Varietas Jepon Mawar Hasil Iradiasi Sinar Gamma
}

\author{
Khoirun Nisak dan Triono B. Saputro \\ Departemen Biologi, Fakultas Ilmu Alam, Institut Teknologi Sepuluh Nopember (ITS) \\ e-mail: trionobsaputro@bio.its.ac.id
}

\begin{abstract}
Abstrak-Tembakau (Nicotiana tabacum) merupakan tanaman dengan nilai ekonomi tinggi. Saat ini tembakau banyak digunakan untuk bahan baku industri rokok, biopestisida, bioinsektisida dan lainnya. Tingkat produksi tembakau dipengaruhi oleh beberapa faktor lingkungan seperti iklim. Dewasa ini fenomena la nina yang mengakibatkan pergeseran iklim berdampak langsung pada tingkat produksi tembakau. Untuk itu dilakukan seleksi tembakau agar didapat tembakau yang tahan terhadap kondisi iklim yang ekstrim dengan cara mutasi iradiasi. Tujuan dilakukan penelitian ini yaitu untuk mengetahui respon perkecambahan tembakau yang telah diiiradiasi. Tembakau diberi perlakuan iiradiasi dengan berbagai konsentrasi yaitu 0 Gy, 10 Gy, 25 Gy, 50 Gy, dan 100 Gy. Biji diamati selama 7 hari. Hasilnya viabilitas dan vigoritas biji tembakau yang telah diiradiasi menunjukkan adannya penurunan perkecambahan dilihat dari daya kecambah, keserempakan tumbuh, dan laju perkecambahan seiring dengan meningkatnya dosis iradisi yang diberikan.
\end{abstract}

Kata Kunci_-Tembakau, Iradiasi, Perkecambahan.

\section{PENDAHULUAN}

$\mathrm{T}$ EMBAKAU (Nicotiana Tabacum) merupakan salah satu komoditas perkebunan utama di Jawa Timur yang memiliki peran penting dalam pembangunan ekonomi regional maupun nasional [1]. Tembakau merupakan tanaman semusim sekali panen pada saat sudah berumur $\pm 90-120$ hari [2]. Salah satu faktor yang mempengaruhi pertumbuhan tembakau adalah iklim. Dewasa ini adanya fenomena El Nino dan La Nina secara global menyebabkan adanya pergeseran iklim yang dapat mempengaruhi pertumbuhan dan produksi tembakau [3].

Hingga saat ini tidak tersedia sumber gen ketahanan untuk sifat tahan kering pada tanaman tembakau. Oleh karena itu diperlukan induksi keragaman. Salah satu metode yang efektif untuk induksi keragaman adalah teknik iradiasi. Induksi keragaman merupakan langkah awal sebelum dilakukan seleksi untuk karakter ketahanan terhadap kekeringan. Selain menggunakan teknik iradiasi, induksi keragaman juga dapat dilakukan dengan menggunakan EMS (Ethyl methanesulfonate), variasi somaklonal, pengkalusan dan lainnya [4].

Iradiasi merupakan salah satu metode yang dapat digunakan untuk melakukan mutasi atau induksi keragaman pada tanaman. Mutasi yang dihasilkan dari perlakuan iradiasi bisa bersifat merugikan atau sebaliknya berisfat menguntungkan [5][6]. Penggunaan mutagen fisik seperti iradiasi sinar gamma banyak dilaporkan penggunaannya dalam upaya mendapatkan varian tanaman dengan berbagai karakter unggul yang diinginkan [7].

Induksi keragaman dapat dilakukan pula menggunakan mutagen kimia seperti EMS. Senyawa EMS merupakan senyawa alkil yang mengubah guanin menjadi 7- etilguanin yang berpasangan dengan timin [8]. Senyawa ini banyak digunakan untuk meningkatkan keragaman genetik tanaman dan perbaikan kualitas tanaman [9]. Salah Satu penelitian yang dilakukan oleh [10], [11] menggunakan EMS sebagai agen mutasi pada tanaman abaka berhasil mendapatkan mutan yang tahan terhadap penyakit layu Fusarium. Keberhasilan mutasi dengan mutagen kimia pada tiap tanaman tergantung pada konsentrasi dan lama perendaman yang digunakan [12].

Selain dua metode diatas, dapat pula digunakan teknik variasi somaklonal sebagai agen mutasi atau induksi keragaman. Variasi somaklonal telah digunakan untuk memperoleh kultivar yang unik dan bermanfaat bagi pemuliaan tanaman secara konvensional. Pada teknik ini kemungkinan terjadinya sifat dominan lebih besar dibandingkan induksi mutasi menggunakan teknik in vivo. Teknik variasi somaklonal yang dilakukan secara in vitro merupakan tahap seleksi genetik yang pertama. Tahap selanjutnya sel akan beregenerasi membentuk variasi somaklonal dan setelah diaklimatisasi, planlet akan menghasilkan tanaman mutan dengan sifat beragam [13], [14].

Dari beberapa metode induksi keragaman tersebut, induksi menggunakan iradiasi sinar gamma lebih dipilih karena jika menggunakan mutagen kimia seperti EMS (ethyl methane sulphonat), DES, etilin amina (EM), etil nitroso urea (ENH), dan metil nitroso urea serta kelompok azida bersifat toksik dan mudah terhidrolisis sehingga menjadi tidak efektif lagi sebagai mutagen [4][15][16]. Induksi mutasi menggunakan teknik iradiasi sinar gamma juga lebih menguntungkan karena dosis yang digunakan lebih akurat dan penetrasi penyinaran ke dalam sel bersifat homogen [17]. Sehingga dapat menghasilkan sifat tau variasi tanaman yang diinginkan.

Dari uraian diatas perlu adanya peningkatan kualitas tanaman tembakau untuk meningkatkan ketahanan terhadap kekeringan. Salah satu cara untuk mendapatkan tanaman yang tahan terhadap kekeringan dapat digunakan metode induksi mutasi. Mutasi dapat dilakukan dengan berbagai cara seperti menggunakan EMS (Ethyl methanesulfonate), iradiasi sinar gamma, subkultur berulang dan pengkalusan [4].

Tembakau memiliki sistem perakaran tunggang dan rambutrambut akar yang tumbuh kesamping. Daun tanaman 
tembakau berbentuk bulat lonjong atau bulat tergantung pada varietasnya. Lapisan atas dari daun tembakau terdiri atas lapisan palisade parenkim dan parenkim spongy pada bagian bawah daun. Umumnya permukaan adaksial dan abaksial daun diselimuti oleh bulu-bulu halus putih. Tanaman tembakau memiliki bentuk batang agak bulat dan termasuk tanaman herbaceous atau tidak berkayu. Tanaman tembakau memiliki bakal buah yang berada diatas dasar bunga dan terdiri dari dua ruang yang dapat membesar. Buah tembakau berbentuk bulat lonjong setiap ruang berisi bakal biji. Bunga dari tanaman tembakau berbentuk seperti terompet dan berwarna putihmerah muda hingga kemerahan. Umumya bunga tembakau termasuk bunga majemuk yang tumbuh di ujung batang, memiliki kelopak bunga yang berbulu, memiliki lima benang sari (anther) dan satu kepala putik [18][19].

Tanaman tembakau pada umumnya tidak menghendaki iklim yang kering maupun iklim yang basah [20]. Tanaman tembakau merupakan tanaman yang sangat peka terhadap perubahan panjang hari atau lama penyinaran sinar matahari. Kurangnya penyinaran matahari menyebabkan terhambatnya pertumbuhan dan produksi tembakau [21].

Tanaman tembakau memiliki banyak varietas atau sub spesies. Namun pada penelitian ini hanya akan digunakan varietas Jepon Mawar yang telah diberi perlakuan iiradiasi dengan berbagai varian konsentrasi. Iiradiasi merupakan salah satu metode yang dapat digunakan untuk melakukan mutasi pada tanaman [22]. Hal ini telah banyak dilaporkan dapat memperbesar ragam genetik tanaman dalam program pemuliaan tanaman seperti pada tanaman padi, kedelai, kacang hijau, gandum dan lain-lain [5].

\section{METODE PENELITIAN}

\section{A. Waktu dan Tempat}

Penelitian ini dilakukan pada bulan Februari 2016 sampai Mei 2016. Penelitian ini dilakukan dalam dua tahap yaitu tahap iradiasi dan tahap pengujian viabilitas dan vigoritas biji. Tahap iradiasi biji dilakukan di Pusat Aplikasi Teknologi Isotop dan Iradiasi (PATIR) BATAN Jakarta. Pengujian viabilitas dan vigoritas biji dilakukan selama satu minggu di Laboratorium Biosains dan Teknologi Tumbuhan Biologi ITS Surabaya.

\section{B. Alat dan Bahan}

Dalam penelitian ini digunakan peralatan antara lain: pinset dan cawan petri. Sedangkan bahan yang digunakan dalam penelitian ini yaitu: biji tembakau varietas Jepon Mawar yang tidak diiiradiasi dan yang diiiradiasi, kapas, akuades, dan kertas strimin.

\section{Biji Tembakau}

Biji tembakau yang digunakna dalam penelitian ini terdiri dari dua jenis yaitu biji tembakau varietas Jepon Mawar (Lihat lampiran) tanpa iradiasi dan biji tembakau varietas Jepon Mawar dengan iradiasi sinar gamma 0 Gy, 25 Gy, 50 Gy, 100 Gy. Kemudian biji akan ditumbuhkan pada medium perkecambahan selama 7 hari. Tembakau dapat dipanen dan diambil bijinya pada saat sudah berumur $\pm 90-120$ hari [2]. Biji yang telah dipanen umumnya disimpan terlebih dahulu dalam cool storage dengan suhu $\pm 10^{\circ} \mathrm{C}$ dan disimpan selama \pm 1 tahun.

\section{Inokulasi Eksplan}

Eksplan yang digunakan berupa biji tembakau. Media perkecambahan berupa kapas yang diatasnya telah diletakkan kertas strimin $10 \times 10$. Media yang telah diberi kertas strimin, disiram menggunakan akuades secukupnya namun tidak sampai menggenang. Kemudian biji tembakau yang diinokulasi ke media perkecambahan. Biji diamati perkecambahannya selama 7 hari.

\section{E. Parameter Pengamatan}

Perkecambahan tanaman diamati dengan cara mengamati proses perkecambahan atau pecah benih dalam waktu 1 minggu. Pada pengamatan perkecambahan biji tembakau dicatat pada hari ke berapa tanaman mulai muncul radikula dan tumbuh planlet hingga muncul 2 daun. Pengamatan biji dilakukan setiap hari.

\section{1) Daya Berkecambah}

Biji tembakau yang berkecambah, kemudian dihitung menggunakan rumus [23] sebagai berikut:

$$
\mathrm{DK}=\frac{\mathrm{JK}}{\mathrm{JC}} \quad \mathrm{X} 100 \%
$$

Keterangan:

DK : Daya kecambah

JK : Jumlah kecambah normal yang dihasilkan

JC : Jumlah contoh benih yang diuji

\section{2) Laju Perkecambahan}

Laju perkecambahan ditentukan dengan menghitung jumlah hari yang diperlukan untuk munculnya radikula atau plumula selama jangka waktu tertentu (7 hari). Menurut Soetopo dalam [23] sebagai berikut:

$$
\mathrm{LP}=\frac{\mathrm{N} 1 \mathrm{~T} 1+\mathrm{N} 2 \mathrm{~T} 2+\mathrm{N} 3 \mathrm{~T} 3 \ldots+\mathrm{NXTX}}{\text { Jumlah total benih yang berkecambah }}
$$

Keterangan:

LP: Laju perkecambahan

$\mathrm{N}$ :Jumlah benih yang berkecambah dalam satuan waktu tertentu

$\mathrm{T}$ : Jumlah waktu antara pengujian awal sampai akhir dari interval tertentu suatu pengamatan

\section{3) Keserempakan Tumbuh}

Keserempakan tumbuh benih dihitung dengan menggunakan presentase kecambah normal kuat pada hitungan antara pengamatan I dan II hari ke-4 menurut Sajad dalam [23] dengan rumus sebagai berikut:

$$
\mathrm{KST}=\frac{\mathrm{KK}}{\mathrm{TB}}
$$

Keterangan:

KST: Keserampakan tumbuh

KK : Jumlah kecambah kuat

TB : Total benih yang dianalisis 


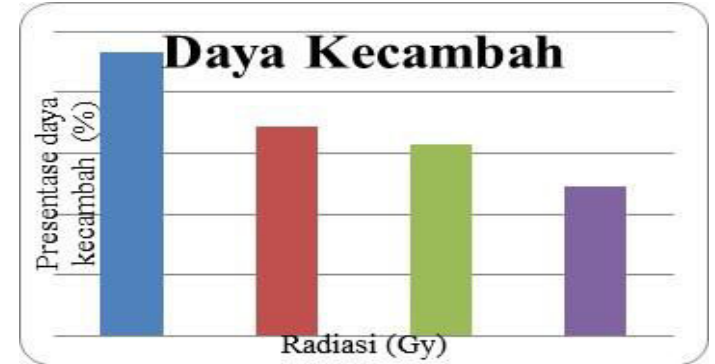

Gambar 1. Grafik daya kecambah tembakau varietas Jepon Mawar terhadap iradiasi sinar gamma dengan berbagai konsentrasi.

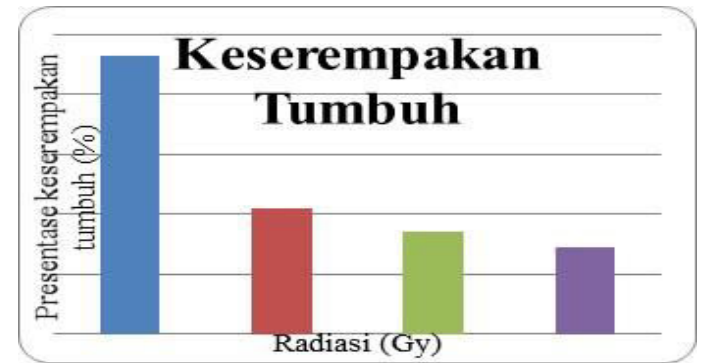

Gambar 2. Grafik keserempakan tumbuh tembakau varietas Jepon Mawar terhadap iradiasi sinar gamma dengan berbagai konsentrasi.

\section{F. Rancangan Penelitian dan Analisis Data}

Rancangan penelitian untuk pengujian vigoritas dan viabilitas biji tembakau menggunakan rancangan acak lengkap dengan satu faktor yaitu dosis iradiasi sinar gamma yang digunakan.

\section{HASIL DAN DISKUSI}

\section{A. Hasil Iradiasi Sinar Gamma pada Viabilitas Biji Tembakau Varietas Jepon Mawar}

Biji tembakau yang diberi perlakuan iradiasi menunjukkan adanya penurunan perkecambahan. Dari daya kecambah (Detail data dapat dilihat gambar 1) dan keserempakan tumbuh (gambar 2) dapat diketahui bahwa biji tanpa iradiasi cenderung berkecambah lebih baik, yaitu $93 \%$ dengan kecambah mati paling sedikit yaitu 7 biji dan 0 biji abnormal. Sedangkan pada iradiasi 25 Gy dan 50 Gy Didapatkan persentase daya kecambah hampir sama yaitu 69\% dan 63\% namun memiliki keserempakan tumbuh yang secara signifikan berbeda. Pada presentase keserempakan tumbuh biji iradiasi 25 Gy didapatkan presentase sebesar $42 \%$ dengan kecambah abnormal 27 kecambah. Sedangkan pada 50 Gy didapatkan presentase sebesar 34\% dengan kecambah abnormal lebih tinggi dibandingkan tanaman kontrol yakni 29 kecambah. Untuk biji tembakau dengan iradiasi 100 Gy memiliki presentase daya kecambah paling rendah dibandingkan dengan tanaman kontrol dan biji yang diiradiasi 25 Gy dan $50 \mathrm{~Gy}$, yakni $49 \%$. Begitu pula denga hasil presentase keserempakan tumbuh, biji iradiasi 100 Gy memiliki presentase paling rendah yaitu $29 \%$ namun memiliki jumlah kecambah abnormal lebih sedikit dibandingkan dengan biji iradiasi 25 Gy dan $50 \mathrm{~Gy}$, yaitu 20 kecambah. Dari tabel 4.3 dapat diketahui tanaman kontrol memiliki laju perkecambahan paling tinggi yaitu sebesar 8,5. Sedangkan untuk biji tembakau dengan iradiasi 25 Gy memiliki laju perkecambahan sebesar
Tabel 1.

Presentase Daya kecambah biji tembakau hasil iradiasi

\begin{tabular}{cc}
\hline \hline Dosis iradiasi (Gy) & $\begin{array}{c}\text { Presentase } \\
\text { perkecambahan }(\%)\end{array}$ \\
\hline 0 & 93 \\
25 & 69 \\
50 & 63 \\
100 & 49 \\
\hline \hline
\end{tabular}

Tabel 2.

presentase keserempakan tumbuh biji tembakau hasil iradiasi

\begin{tabular}{ccc}
\hline \hline Dosis iradiasi (Gy) & $\begin{array}{c}\text { Presentase } \\
\text { perkecambahan }(\%)\end{array}$ & $\begin{array}{c}\text { Jumlah kecambah } \\
\text { abnormal }\end{array}$ \\
\hline 0 & 93 & 0 \\
25 & 42 & 27 \\
50 & 34 & 29 \\
100 & 29 & 20 \\
\hline \hline
\end{tabular}

Tabel 3.

Laju perkecambahan biji tembakau hasil iradiasi

\begin{tabular}{cc} 
iradiasi (Gy) & Laju perkecambahan \\
\hline 0 & 8,5 \\
25 & 8,3 \\
50 & 8,2 \\
100 & 8,2 \\
\hline
\end{tabular}

8,3. Sedangkan biji iradiasi 100 Gy dan 50 Gy memiliki laju perkecambahan yang sama yaitu 8,2 .

\section{B. Pengaruh Iradiasi Sinar Gamma terhadap Vigoritas Biji Tembakau Varietas Jepon Mawar}

Meskipun persentase perkecambahan yang diperoleh dari uji perkecambahan cenderung tinggi, namun setiap dosis menunjukkan jumlah kecambah abnormal yang berbeda. Hal ini sesuai dengan pernyataan [24] yaitu pada beberapa percobaan radiasi pada benih, radiasi pada dosis rendah dapat meningkatkan persen perkecambahan, namun jika radiasinya terlalu tinggi maka benih-benih tersebut akan mati. Penurunan perkecambahan pada uji perkecambahan terjadi seiring dengan meningkatnya dosis iradiasi pada penelitian, tergantung pada pemberian radiasi sinar gamma [25]. Dosis iradiasi yang digunakan dan pengaruhnya terhadap perkecambahan benih berbeda-beda untuk tiap jenis dan genotipe. Namun secara umum, dosis iradiasi yang lebih tinggi cenderung menghambat perkecambahan [26].

Pada biji kontrol (tanpa iradiasi) hasil yang didapatkan tidak $100 \%$, baik pada perhitungan laju perkecamabhan, daya kecambah maupun keserempakan tumbuh. Hal ini dimungkinkan biji yang digunakan memiliki vigoritas yang kurang baik. Biji yang mempunyai kekuatan tumbuh (vigor) yang baik akan menjadi cepat proses reaktivasi metebolismenya apabila kondisi lingkungan tumbuh optimum dan proses metabolisme biji tidak terhambat. Biji dengan vigor yang baik akan mempunyai nilai keserempakan tumbuh yang tinggi. Sebaliknya, biji yang mempunyai vigor buruk akan berpengaruh terhadap fisiologi maupun morfologi tanaman yang dihasilkan [27].

Dalam penelitian [28] melaporkan juga bahwa iradiasi benih pepaya dosis 10 Gy meningkatkan persentase perkecambahan menjadi $50 \%$ dari kontrol $30 \%$. Hal ini sesuai dengan uji perkecambahan pada penelitian iradiasi tembakau dimana terjadi penurunan presentase daya kecambah dan keserempakan tumbuh pada dosis iradiasi tertinggi $100 \mathrm{~Gy}$. 


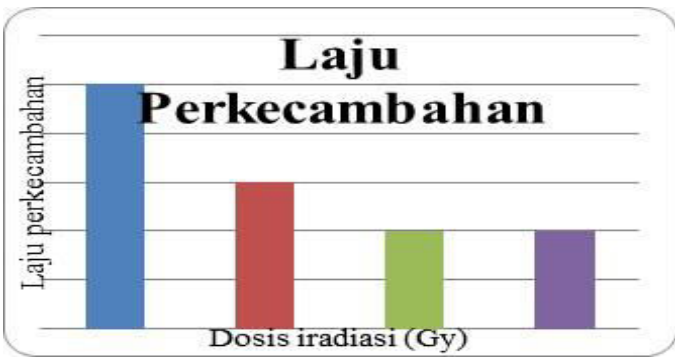

Gambar 3. Grafik laju perkecambahan biji tembakau varietas Jepon Mawar terhadap iradiasi sinar gamma dengan berbagai konsentrasi.

Hasil yang didapat pada penelitian ini juga menunjukkan kecenderungan yang sama dengan yang ditemukan oleh [29] dan [30] yang menyatakan bahwa iradiasi dosis tinggi dapat mengurangi perkecambahan benih. Fenomena ini dikenal dengan istilah pengaruh hormesis yang didefinisikan [31] sebagai stimulasi dengan dosis rendah iradiasi ionisasi dan penghambatan pada dosis yang tinggi.

Dosis iradiasi rendah yang digunakan pada biji, umbiumbian, dan spora dilaporkan dapat mempercepat proses perkecambahan, mempercepat proses pertumbuhan, dan meningkatkan hasil akhir pada saat dipanen. Sebaliknya, dosis yang tinggi akan mengakibatkan adanya penghambatan pertumbuhan atau bahkan letal pada tanaman [32][33], dan [34]. Namun terdapat pula faktor fisiologi yang dapat meningkatkan bahaya iradiasi pada tanaman seperti suhu, air, konsentrasi oksigen, dan ketersediaan nutrisi [34]. Iradiasi yang dilakukan pada benih, secara umum memiliki kisaran dosis efektif yang lebih tinggi dibandingkan jika dilakukan pada bagian tanaman lainnya, yaitu berkisar 50 Gy - $250 \mathrm{~Gy}$ [16]. Umumnya dosis optimum dalam induksi mutasi yang dapat menimbulkan keragaman dan menghasilkan mutan terbanyak biasanya terjadi di sekitar $\mathrm{LD}_{50}$ yaitu tingkat dosis yang menyebabkan kematian sebesar $50 \%$ dari populasi tanaman yang diiradiasi [33]. Seperti yang terlihat dari daya kecambah tanaman dengan dosis iradiasi 100 Gy dengan daya kecambah hanya $49 \%$.

Pada uji keserempakan tumbuh didapatkan hasil dimana kecambah tidak serempak pertumbuhannya seiring meningkatnya dosis iradiasi. Keserempakan tumbuh merupakan salah satu parameter vigor. Cara yang digunakan adalah dengan menghitung persentase kecambah normal kuat pada hari ke-7. Hal tersebut menunjukkan bahwa iradiasi sinar gamma menyebabkan vigor benih menurun, akibat pengaruh radiosensitivitas masing-masing varietas berbeda [35]. Perlakuan iradiasi pada benih menyebabkan kerusakan fisik (physical damage) yaitu menurunkan daya pertumbuhan tanaman. Semakin tinggi dosis iradiasi akan semakin menghambat pertumbuhan [36]. Indikasi biokimia dalam benih yang mengalami kemunduran viabilitas dan vigoritas menurut [37] adalah (a) perubahan aktivitas enzim (b) perubahan laju respirasi; (c) perubahan di dalam cadangan makanan; (d) perubahan di dalam membran, dan (e) kerusakan kromosom. Hal ini terjadi karena prinsip kerja sinar gamma yaitu menghasilkan radikal bebas yang reaktif dan bereaksi dengan molekul dalam sistem biologi, sehingga mengacaukan proses proses biokimia di dalam sel sehingga mengganggu homeostatis/keseimbangan sel [16].

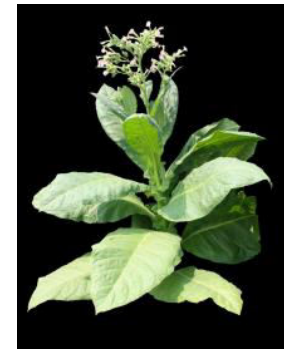

a

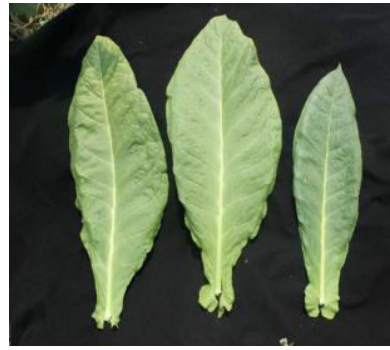

b
Gambar 4. a. tanaman tembakau Jepon Mawar, b. daun tembakau Jepon Mawar

Selain itu ketidakserempakan kecambah tumbuh dapat dikarenakan oleh faktor fisiologi dalam benih tersebut sehingga dapat menurunkan daya tumbuh kecambah. Penurunan daya tumbuh benih menurut [37] dapat ditunjukkan oleh gejala fisiologis sebagai berikut: (a) terjadinya perubahan warna benih (b) tertundanya perkecambahan; (c) menurunnya toleransi terhadap kondisi lingkungan suboptimum selama perkecambahan (d) rendahnya toleransi terhadap kondisi simpan yang kurang sesuai (e) peka terhadap radiasi; (f) menurunnya pertumbuhan kecambah; (g) menurunnya daya berkecambah, dan (h) meningkatnya jumlah kecambah abnormal.

Dalam penelitian [25] melaporkan bahwa untuk mendapatkan individu yang memperlihatkan perubahan sifat (mutan) tergantung pada jenis tanaman, fase tumbuh, ukuran, kekerasan, dan material uji. Pemanfaatan radiasi sinar gamma pada berbagai konsentrasi diharapkan mendapatkan jenis varietas unggul yang mempunyai karakter lebih baik dari sebelumnya. Seperti yang dilaporkan oleh [17] bahwa iradiasi sinar gamma dapat meningkatkan daya kecambah dan kecepatan berkecambah sengon (Albizia falcataria) pada dosis rendah yaitu 5 Gy sampai 90 Gy. Sedangkan [38] melaporkan padi varietas Situ Bagendit yang diiradiasi sinar gamma mengalami penurunan perkecambahan seiring dengan meningkatnya dosis iradiasi yaitu 200 Gy dan 300 Gy. Namun mengalami peningkatan perkecambahan dan pertumbuhan pada dosis 100 Gy. Begitu pula dalam penelitian [39] menggunakan kalus embrio somatik kacang tanah varietas Lokal Bima yang mengalami pertumbuhan maksimal pada iradiasi sinar gamma dengan dosis rendah 15 Gy dan 20 Gy. Sedangkan pada iradiasi 25 Gy kalus terjadi penurunan pertumbuhan.

\section{KESIMPULAN}

Viabilitas dan vigoritas biji tembakau yang telah diiradiasi menunjukkan adannya penurunan perkecambahan dilihat dari daya kecambah, keserempakan tumbuh, dan laju perkecambahan seiring dengan meningkatnya dosis iradisi yang diberikan.

\section{LAMPIRAN}

Tembakau (N. tabacum) varietas Jepon Mawar umumnya memiliki tinggi tanaman sedang antara 119,6 cm-149,8 cm. Tembakau ini memiliki warna batang hijau kekuningan dan sepanjang batang diselimuti oleh bulu-bulu halus. Bentuk daun tembakau (N. tabacum) Jepon Mawar bulat memanjang 
dengan tepi daun licin atau rata. Dalam satu tanaman umumnya memiliki jumlah daun 20-26 lembar atau rata-rata 23 lembar daun. Memiliki panjang daun 48,3cm-77,0cm atau rata-rata $62,5 \mathrm{~cm}$ serta lebar daun $31,2 \mathrm{~cm}-42,5 \mathrm{~cm}$ atau rata-rata $36,8 \mathrm{~cm}[40]$.

\section{DAFTAR PUSTAKA}

[1] Dinas Perkebunan Provinsi Jawa Timur, "Komoditi Tanaman Tembakau," 2016.

[2] A. Suwarso, A. Herwati, and S. Rachman, "Pemuliaan Tembakau Madura," Malang, 1999.

[3] T. Yohannes, M. Andargie, and A. Takele, "In Vitro Screening for Drought Tolerance in Different Sorghum (Sorghum bicolor (L.) Moench) Varieties," J. Stress Physiol. Biochem., vol. 9, no. 3, 2013.

[4] R. Yunita, "Pemanfaatan Variasi Somaklonal Dan Seleksi In Vitro Dalam Perakitan Tanaman Toleran Cekaman Abiotik," J. Litbang Pertan., vol. 28, no. 4, pp. 142-148, 2009.

[5] H. Soeharto, "Pemuliaan Mutasi Pada Sorghum (Sorghum Bicolor L.) Untuk Perbaikan Tanaman Sebagai Pakan Ternak Ruminansia," Jakarta, 1998.

[6] D. Ermavitalinia, I. P. Sari, E. N. Prasetyo, N. Abdulgani, and T. B. Saputro, "Effect of Gamma 60Co Irradiation On The Lipid Content and Fatty Acid Composition of Nannochloropsis sp. Microalgae," in Proceeding of International Biology Conference, 2016.

[7] I. S. Aisyah, A. Hajrial, S. Asep, M. Budo, and S. Sarsidi, "Induksi Mutasi Pada Stek Pucuk Anyelir (Danthus caryophyllus Linn.) Melalui Iradiasi Sinar Gamma," J. Agron Indones., vol. 37, no. 1, pp. 62-70, 2009.

[8] C. VL. Mutagenesis, "Investigating the process and processing the outcome for crop improvement," J. Curr. Sci., vol. 89, pp. 353-359, 2005.

[9] \ M. Imelda, P. Deswina, S. Hartati, Estiati, and S. Atmowijoyo, "Chemical Mutation by Ethyl Methane Sulfonate (EMS) for Bunchy Top Virus Resistence in Banana," Ann. Bogor., vol. 38, no. 3, pp. 205-211, 2000.

[10]R. D. Purwati, U. Budi, and S. Sudarsono, "Penggunaan Asam Fusarat dalam Seleksi in vitro untuk Resistensi terhadap Fusarium oxysporum f.sp. cubense," J. Littri, vol. 7, no. 2, pp. 80-91, 2007.

[11]R. D. Purwati, K. E. Sudjindro, and S. Sudarsono, "Keragaman Genetika Varian Abaka yang Diinduksi dengan Ethyl Methane Sulphonate (EMS)," J. Littri, vol. 15, no. 4, pp. 152-161, 2008.

[12] Y. Yanti, "Banana Treatments of Ethyl Methane Sulphonate Muthagen Throuhg In Vitro," in The Third Asian Conference on Plant Pathology, 2007, pp. 467-471.

[13] S. Soedjono, "Aplikasi Mutasi Induksi Dan Variasi Somaklonal Dalam Pemuliaan Tanaman," J. Litbang Pertan., vol. 22, no. 2, 2003.

[14]T. B. Saputro, S. Dianawati, N. F. Sholihah, and D. Ermavitalini, "Genetic diversity of improved salt tolerant calli of maize (Zea mays L.) using RAPD," in Proceeding of International Biology Conference, 2016.

[15]IAEA, "Manual On Mutation, Viability And Population Structure," Acta Agric. Cand, vol. 4, pp. 601-632, 1997.

[16] A. M. Van Harten, Mutation breeding. Theory and Practical Aplications. USA: Cambridge University Press, 1998.

[17]Litbang Pertanian, "Teknik Mutasi Untuk Pemuliaan Tanaman," 2014. .

[18] Listyanto, Budidaya Tembakau (Nicotiana tabacum L.) Menggunakan Pupuk Hayati Bio Z. Jakarta: PT Alam Lestari Maju Indonesia, 2010.

[19] K. Kamal, "Monograph Of Tobacco (Nicotiana tabacum)," Indian J. Drugs, vol. 2, no. 1, pp. 5-23, 2014.

[20] BAPPEDA Kendal, "Tentang Tembakau," 2016. .

[21]P. J. G. Smykal, D. B. Stefanie, R. Venkatesh, and M. Siegbert, "Flowering Of Strict Photoperiodict Nicotiana Varieties In Non-Inductive
Condition By Transgenic Approaches," Plant Mol Bio, vol. 6, 2007.

[22]M. Zanzibar and Witjaksono, "Pengaruh Penuaan Dan Iiradiasi Benih Dengan Sinar Gamma (60C) Terhadap Pertumbuhan Bibit Suren (Toona sureni Blume Merr)," J. Penelit. Hutan Tanam., vol. 8, no. 2, pp. 89-95, 2011.

[23]M. K. Lesilolo, J. Patty, and N. Tetty, "Penggunaan Desikan Abu dan Lama Simpan terhadap Kualitas Benih Jagung (Zea mays L.) pada Penyimpanan Ruang Terbuka," Agrogolia, vol. 1, no. 1, pp. 51-59, 2012.

[24]N. D. S. Daeli, A.P.P.Lollie, and N. Isman, "Pengaruh Radiasi Simar Gamma Terhadaptanaman Kacang Hijau (Vigna radiata L.) Pada Kondisi Salin," J. Online Agroekoteknologi, vol. 1, no. 2, 2013.

[25]G. N. Sutapa and I. G. A. Kasmawan, "Efek Induksi Mutasi Radiasi Gamma 60co Pada Pertumbuhan Fisiologis Tanaman Tomat (Lycopersicon esculentum L.)," J. Keselam. Radiasi dan Lingkung., vol. 1, no. 2, 2016.

[26] M. Zanzibar and D. J. Sudrajat, "Prospek Dan Aplikasi Teknologi Iradiasi Sinar Gamma Untuk Perbaikan Mutu Benih Dan Bibit Tanaman Hutan," Jakarta, 2009.

[27]D. S. Rini, Mustikoweni, and T. Surtiningsih, "Perkecambahan Benih Sorgum (Sorghum bicolor L. Moench) Terhadap Perlakuan Osmoconditioning Dalam Mengatasi Cekaman Salinitas," Ber. Biol., vol. 7, no. 6, 2005.

[28]Y. K. Chan and P. F. Lam, "Irradiation-Induced Mutations In Papaya With Special Emphasis On Papaya Ringspot Resistance And Delayed Fruit Ripening. Working Material - Improvement Of Tropical And Subtropical Fruit Trees Through Induced Mutations And Biotechnology," Vienna, pp. 35- 45, 2002.

[29]K. G. Hell and M. Silveira, "Imbibition And Germination Of Gamma Irradiation Phaseolus vulgaris Seeds," F. Crop Abst, vol. 38, no. 6, p. 300, 1974.

[30]D. Marcu, V. Cristea, and L. Daraban, "Dose-dependent effects of gamma radiation on lettuce (Lactuca sativa var. capitata) seedlings," Int. J. Radiat. Biol., pp. 1-5, 2012.

[31]T. Luckey, "Radiation Hormesis Overview," RSO Mag., vol. 4, pp. 1936, 2003.

[32]H. Ali, G. Zoya, S. Sandal, and G. Alvina, Effect Of Gamma Radiation On Crop Production. Springer, 2016.

[33] Asadi, "Peran Sumberdaya Genetik Pertanian Bagi Pemuliaan Mutasi" Dalam Mugiono, D. Sopandi, S. Hudiyono, N. Kuswandi, Z. Irawati, P. Sidauruk, H. Winarno, Sobrizal, dan R. Chosdu (eds.)," in Prosiding Simposium dan Pameran Teknologi Aplikasi Isotop dan Radiasi, 2011.

[34]M. G. Hale and D. M. Orcutt, The Physiology Of Plant Under Stress. New York: John Wiley \& Sons Inc, 1987.

[35]F. C. Indriani, H. Kuswantoro, R. T. Hapsari, and A. Supeno, "Radiosensitivitas Beberapa Varietas Kedelai Terhadap Iradiasi Sinar Gamma," in Prosiding Seminar Hasil Penelitian Tanaman Aneka Kacang dan Umbi, 2012.

[36]T. D.S. Hanafiah, S. Yahya, and D. Wirnas, "Studi Radiosensitivitas Kedelai (Glycine max (L.) Merr) Varietas Argomulyo Melalui Iradiasi Sinar Gamma," Bionatura, vol. 12, no. 2, pp. 105-111, 2010.

[37]B.H. Siwi, "Pengaruh Radiasi Sinar Gamma (Co-60) Terhadap Beberapa Varietas Padi Di Indonesia," 2016. [Online]. Available: http://www.digilib.batan.go.id/e-prosiding/pdf.

[38]Y. C. F. Salsinha, "Pengaruh Iradiasi Sinar $\Gamma$ (Gamma) Co-60 Terhadap Pertumbuhan Padi (Oryza Sativa) 'Situ Bagendit' Pada Cekaman Kekeringan," Pap. J. Fak. Biol., 2015.

[39]A. F. Hermon, "Induksi Mutasi Dengan Iradiasi Sinar Gamma Dan Seleksi In Vitro Untuk Identifikasi Embrio Somatik Kacang Tanah Cv. Lokal Bima Yang Toleran Pada Media Polietilen Glikol," Crop. Agro, vol. 3, no. 1, pp. 65-71, 2010.

[40]PT. SADHANA, Buku Kunci Identifikasi Tanaman Tembakau. Sadhana Agro Center, 2015. 